\section{German minister backs more growth for basic research}

Bonn. In his first statement on research policy since taking office last November, Germany's new minister for education and research, Jürgen Rüttgers, has promised that basic research can expect to receive a continued increase in support from the federal government.

In particular, Rüttgers has expressed his backing for a new five-year financing agreement with the Max Planck Gesellschaft (MPG), which runs basic research institutes, and the Deutsche Forschungsgemeinschaft (DFG), which provides grants for basic research projects, mainly in universities.

This agreement, which would run from 1996 to 2000, would succeed the previous 'five-by-five' agreement which has guaranteed both institutions a five per cent budget rise during the first half of the $1990 \mathrm{~s}$, at a time when basic research elsewhere in Europe has fallen victim to the economic recession.

Rüttgers, who took over a new ministry combining education and research (BMBF) last November, has put forward his plans in a document published in Bonn earlier this month. In it, he outlines his strategy for providing long-term support for Germany's industrial competitiveness by reforming higher education and providing a strong base in both basic and applied research.

On the question of additional funds for basic research through the DFG and MPG, Rüttgers admits that his ministry cannot do this on its own, as a final decision will require the support not only of the federal finance minister, but also of the Länder, which foot half of the bill for both agencies. But he says that such agreement is essential for the long-term planning of basic research.

Rüttgers is more reserved about the future of Germany's 16 national research centres. While emphasizing that the centres are essential for long-term and interdisciplinary research programmes, he also indicates that he intends to keep pressure on them to serve industry's needs more directly.

Rüttger's main concern is the reduction in research support by industry, whose share of total research funding in Germany fell from 62 per cent in 1989 to 59 per cent in 1993. The most recent figures for last year suggest that this downward trend is continuing, and Rüttgers is keen to help correct the situation.

Under one initiative, for example, the BMBF is to set up a group to suggest how Germany's notoriously bureaucratic licensing procedures, particularly those relating to safety issues, might be modified to create a more research-friendly environment in industry.

The ministry will also be responsible for organizing the activities of a new council for

research, technology and innovation being set up by the chancellor, Helmut Kohl, to advise him on ways in which the scientific community and industry can work together more productively. The members of the council are expected to be named shortly. One of their first topics for discussion is likely to be information technology, a field in which Germany lags internationally.

Rüttgers has also broken with traditional reticence on Germany's nuclear research programme - now confined to decommissioning and general safety issues - by saying that the BMBF should support young scientists working in nuclear energy and reactor

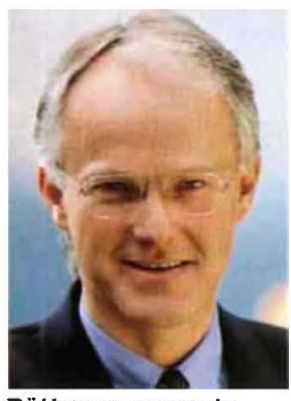

Rüttgers: power to introduce changes

mood turn pronuclear.

Biotechnology will also benefit from Rüttger's regime. The minister says that he strongly supports Germany's increased participation in the human genome programme, and has proposed spending DM50 million (US\$33 million) a year, ten times more than the current funds available through the DFG, for studies in human genetic diseases.

All this will cost money. The 1995 budget, delayed by last autumn's general election, will probably not be approved until April at the earliest. But Rüttgers is confident of obtaining an increase for research close to the 2.7 per cent that he proposed at the end of last year. The statement put out by the new coalition government shortly after the election spoke of "higher than average" financial support for the BMBF.

Rüttgers silence up to now on his policies has been the result of the time taken to merge the education and research ministries. The process - now completed was far from painless, as many experienced staff lost their posts.

But Rüttgers can now draw higher education into his plans to create an environment to support long-term industrial and cultural needs. He plans to implement changes that have long been debated, and may well have more power to do so then his predecessors through his often scorned, but nonetheless influential, title of "minister for the future".

Alison Abbott
Dutch universities 'need shorter courses for undergraduates'

Munich. The Dutch Scientific Council for Government Policy has come out in support of a government proposal to abandon the 'continental' system of university education of relatively long undergraduate courses in favour of a system with shorter (and cheaper) courses similar to those offered by British universities.

In the Netherlands, as in most continental countries, every student with a highschool leaving certificate has the right to a university place. In practice, this has led to overcrowding of universities and little teacher-student contact. Students tend to take up to six years to complete a degree course, which includes a significant research component.

According to a report published last week, the science council says that a student's right to university education should be defended. But it says that there should be more rigorous selection after the first year of study. At present, most students only sit the first selection examination when they feel adequately prepared for it - which can often be three years after the start of their studies. As a result, few are filtered out at that stage.

The report also argues that the traditional von Humboldt method of education, in which all undergraduate students are given a training in research, is inappropriate nowadays It suggests that the total length of undergraduate degrees should be shortened to three years by reducing or removing the research component. Students wishing to pursue a career in research would then go on to take a further degree.

But Dutch universities are not happy about abandoning the von Humboldt system. In a report of their own, published a week earlier, they argue that shortening courses would lower standards. Ruut de Moor, the former rector of Brabant University who headed the committee responsible for the report, argues that "this would make us an exception in continental Europe".

The universities agree that the first selection examination for undergraduates should be tougher, but say that students should be allowed two years to prepare for it. The government will now debate the two reports and is expected to make a policy statement in September.

The government has already backed down from its demands for an annual saving of DFl,500 million in higher education costs by 1998 (see Nature 371, 95; 1994). At the end of December, it agreed with the universities to reduce the annual saving to $\mathrm{DFl}, 200$ million, to be achieved in stages by the year 2004. Much of the saving, the government hopes, will come from the proposed shorter study time currently being debated. A. A. 